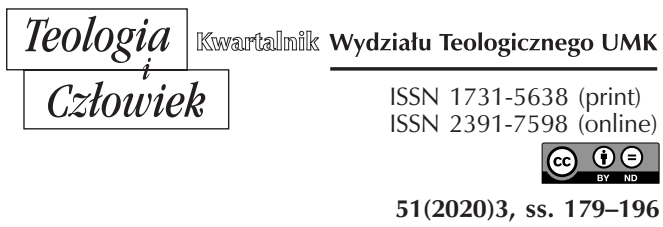

MIROSŁAW RUCKI

UNIWERSYTET TECHNOLOGICZNO-HUMANISTYCZNY IM. K. PUŁASKIEGO W RADOMIU

MIROSLAW.RUCKI@GMAIL.COM

ORCID 0000-0001-7666-7686

\title{
PROGRAM FORMACYJNY RUCHU WIERNYCH SERC JAKO PROPOZYCJA SPOSOBU WYJŚCIA Z KRYZYSU
}

DOI: http://dx.doi.org/10.12775/TiCz.2020.045

Streszczenie. Artykuł przedstawia problem małżonków w kryzysie, ze szczególnym uwzględnieniem stanu osoby zdradzonej i porzuconej. Bazując na danych literaturowych i wskazówkach dotyczących pomocy w sytuacjach kryzysowych, opracowano program spotkań biblijnych wzmacniających czynnik religijny, wspierający radzenie sobie w sytuacji kryzysowej. Osoby, które pragną zachować wierność małżeńską nawet pomimo niewierności współmałżonka, dzięki systematyczności prowadzonych spotkań i trwaniu w praktykach religijnych mają szansę na szybsze odzyskanie zdolności do pełnienia ról społecznych, wyciszenie silnych emocji negatywnych, przywrócenie równowagi wewnętrznej, a nade wszystko ponowne dostrzeżenie sensu życia.

Słowa kluczowe: wierność; małżeństwo; kryzys.

Abstract. Movement of Faithful Hearts formation program: a proposition for coping with crisis. In the paper, problem of marriage crisis is dealt. Especially it is focused on the spouse, who is a victim of infidelity. Literature and guides on crisis intervention were used for the proposition of the Biblical course aimed to support people in dealing with the crisis, because religion is a recognized positive factor. The course is proposed to the persons who have decided to keep faithfulness despite of infidelity of spouse. Systematically conducted meetings and keeping religious activities are helpful in their efforts to restore their ability to play a social role, to calm down 
strong negative emotions, to restore the inner balance, and above all to see the meaning of life again.

Keywords: faithfulness; marriage; crisis.

\section{WPROWADZENIE}

Doświadczenie życia codziennego oraz analiza danych socjologicznych prowadzą do konkluzji, że „realizacja nauczania Kościoła o nierozerwalności małżeństwa nie ma adekwatnego przełożenia na życie małżeńskie"'. W USA nawet pragmatyczny bilans ujemnych i dodatnich skutków zawierania małżeństwa nie wpływa pozytywnie na liczbę ani trwałość zawieranych związków: „Mimo iż korzyści płynących ze związków sakramentalnych jest więcej, to jednak amerykańskie społeczeństwo nie przyjmuje ich do wiadomości, co więcej, akceptuje pozamałżeńskie i alternatywne relacje seksualne (w tym również związki homoseksualne)"².

Trwałość i stabilizacja to najważniejsze oczekiwania wobec związku małżeńskiego, które powodują, że nawet osoby, mające pozytywny stosunek do związków nieformalnych, same wolą nie pozostawać w konkubinacie ${ }^{3}$. Powszechność doświadczenia rozwodu prowadzi nawet do wniosku, że „zazwyczaj normatywny cykl życia rodziny trzeba uzupełnić o fazę rozwodu i czas po rozwodzie"4.

$\mathrm{Z}$ rozmaitych badań wynika, z jednej strony, że związek małżeński może być jednym z najsilniejszych korelatów szczęścia i dobrostanu psychicznego, a z drugiej, źródłem silniejszych emocji negatywnych, wyższego poziomu napięcia psychicznego oraz niższej satysfakcji z życia ${ }^{5}$.

1 J. Kułaczkowski, Rozwód a duszpasterstwo rodzin, w: Rodzina w nurcie współczesnych przemian, red. D. Krok, P. Landwójtowicz, Opole 2010, s. 45-65.

2 A. Kłos-Skrzypczak, Korzyści płynące z rodziny zakorzenionej $w$ małżeństwie sakramentalnym - perspektywa Amerykańskich Biskupów Katolickich, „Family Forum” 7 (2017), s. 15-34.

3 A. Kwak, Rodzina i jej przemiany, Warszawa 1994, s. 72-73.

${ }^{4}$ W. Sikorski, Zmienność interakcji $w$ rodzinie uwarunkowana naturalnymi procesami jej rozwoju, w: Rodzina w nurcie współczesnych przemian, red. D. Krok, P. Landwójtowicz, Opole 2010, s. 89-102.

${ }^{5}$ D. Krok, Satysfakcja ze związku małżeńskiego a poziom hedonistycznego 
Prawdopodobnie kryzys związany ze zdradą małżeńską i wynikający $\mathrm{z}$ niej rozwód stanowią największe zagrożenie dla rodziny i wszystkich jej członków, gdyż prowadzi do zburzenia systemu rodzinnego, który funkcjonował już przez jakiś czas i wypracował własne mechanizmy rozwiązywania bieżących problemów. Można spotkać się ze stwierdzeniem, że kryzys wywołany przez zdradę jest jednym z najczęstszych powodów zwracania się do osób trzecich o pomoc ${ }^{6}$. Dodatkowa trudność pojawia się wtedy, gdy druga strona (inicjująca zdradę i rozwód) nie wyraża zgody na mediacje i negocjacje, dążąc tylko i wyłącznie do rozwodu. Mamy wówczas do czynienia z kryzysem osoby, rozpaczliwie potrzebującej pomocy.

Poniższe opracowanie przedstawia jeden z możliwych sposobów udzielenia pomocy osobom przechodzącym przez taki właśnie kryzys, z uwzględnieniem nauczania o nierozerwalności małżeństwa, a także innych czynników o charakterze religijnym i psychologicznym.

\section{DEFINICJE KRYZYSU}

Robiąc przegląd definicji kryzysu osoby, James i Gilliland ${ }^{7}$ wymieniają 9 głównych, które można w skrócie opisać jako:

1) niemożność osiągnięcia ważnego celu życiowego,

2) traumatyczne wydarzenie, nieprzewidziane i niekontrolowane,

3) osoba nie wie, jak ma zareagować w danej sytuacji,

4) sytuacja uniemożliwia działanie i blokuje możliwość świadomego wpływu na własne życie,

5) dezorganizacja powodująca frustrację dotyczącą ważnego celu życiowego, zaburzenie cyklu życia i nieskuteczność dotychczasowych sposobów radzenia sobie w trudnych sytuacjach,

6) tymczasowa utrata zdolności radzenia sobie z problemami,

7) utrata równowagi psychologicznej z elementami depresji i lęku, wywołane przez czynniki zewnętrzne,

i eudajmonistycznego dobrostanu psychicznego mał̇zonków, „Family Forum” 5 (2015), s. $141-160$.

${ }^{6}$ A. Serafin, M. Czyż, Zdrada, https://psychologiapar.pl/2014/zdrada/ (dostęp: 13.05.2018).

7 R.K. James, B.E. Gilliland, Crisis Intervention Strategies, Belmont 2013, s. 7-8. 
8) kontekst kliniczny związany z sytuacją, gdzie nie działają dotychczasowe sposoby radzenia sobie z problemami,

9) wydarzenie o charakterze katastrofalnym albo seria stresów powodująca utratę równowagi psychologicznej.

Właściwie każda z tych definicji dość dobrze opisuje stan osoby zdradzonej i porzuconej przez współmałżonka. W tej sytuacji można mówić o katastrofalnym czynniku kryzysowym, jeśli zastosować rozróżnienie opisane przez McCubbina i Figleya ${ }^{8}$ (2014). Katastrofalny czynnik wywołujący poczucie kryzysu (w odróżnieniu od normatywnego) charakteryzuje się tym, że nie ma czasu na przygotowanie się, jest niemożliwy do przewidzenia, nie jest związany z poprzednim doświadczeniem życiowym, nie ma wypracowanych schematów radzenia sobie z sytuacją, rzadko jest możliwość skorzystania z doświadczenia innych ludzi, czas trwania sytuacji kryzysowej może być bardzo długi, poczucie kontroli nad sytuacją jest małe lub żadne, oraz bardzo duże jest: poczucie bezradności, poczucie utraty, poczucie zburzenia, poczucie niebezpieczeństwa. W związku z tym kryzysem pojawia się wiele problemów emocjonalnych i medycznych ${ }^{9}$. Kryzys nie jest zjawiskiem liniowym; przypomina często teorię chaosu z przyspieszeniami, zatrzymaniami, powtórnym działaniem i zwrotami o 180 stopni $^{10}$. W II tomie pracy zbiorowej ${ }^{11}$ omawiane są szczegółowo takie czynniki o charakterze katastrofalnym, jak: choroba, uzależnienie od narkotyków, porzucenie, śmierć, bezrobocie, gwałt, kataklizm, wojna, porwanie. W przypadku porzucenia zastosowano model ABCX, zakładający odnalezienie $\mathrm{w}$ rodzinie zasobów na przejście przez kryzys, oraz wypracowanie alternatywy dla zburzonych relacji małżeńskich.

W Podręczniku rozwodów jeden z rozdziałów poświęcono przewidywalności rozwodu ${ }^{12}$. Wydaje się jednak, że analiza czynników zwiększających

${ }^{8}$ H.I. McCubbin, C.R. Figley, Bridging Normative and Catastrophic Family Stress, in: Stress and the family: Coping with normative transitions (Vol. 1), McCubbin, H.I., Figley, C.R. (Eds.), New York 2014, p. 218-228.

9 Tamże.

${ }^{10}$ R.K. James, B.E. Gilliland, Crisis, s. 51.

${ }^{11}$ C.R. Figley, H.I. McCubbin (Eds.), Stress And The Family: Coping With Catastrophe, New York 2016.

12 A.E. Rodrigues, J.H. Hall, F.D. Fincham, What Predicts Divorse and Relationship Dissolution?, in: Handbook of Divorce and Relationship Dissolution, M.A. Fine, J.H. Harvey (Eds.), New York-London 2006, p. 85-112. 
„przewidywalność” rozwodu nie zmniejsza jego katastrofalnego charakteru dla osoby zdradzonej i porzuconej. Wręcz przeciwnie, wygląda na to, że przyjęcie nierozerwalności związku małżeńskiego za normę przyczynia się do trwałości małżeństwa i dążenia do rozwiązywania problemów, podczas gdy dopuszczenie możliwości rozwodu stwarza warunki do takiego właśnie „rozwiązania” problemów małżeńskich przez rozcięcie węzła małżeńskiego.

\section{CZYNNIK RELIGIJNY I PIERWSZA POMOC}

James i Gilliland ${ }^{13}$ zauważają, że negowanie roli religii i duchowości w sytuacjach kryzysowych oznacza ignorowanie sposobu, w jaki większość ludzi reaguje na sytuacje kryzysowe. Poza poradnictwem duchowym, prawie nikt nie zajmuje się wpływem przekonań religijnych na rozwiązywanie problemów w kryzysach. Niemniej jednak, podkreśla autor, dla wielu osób trauma łączy się z utratą poczucia sensu, a przecież większość ludzi wiąże sens życia $\mathrm{z}$ jakimś rodzajem wiary.

W sytuacjach kryzysowych konieczne jest udzielenie pierwszej pomocy. Odnosząc się przeważnie do kataklizmów lub doświadczenia "ocaleńców” wojennych, Kanel ${ }^{14}$ wypunktowuje następujące działania, niosące pomoc osobie w kryzysie:

1. Kontakt i zaangażowanie (odpowiedź na chęć nawiązania kontaktu).

2. Bezpieczeństwo i pocieszenie (udzielenie natychmiastowej pomocy w postaci wysłuchania i stworzenia psychicznego i emocjonalnego poczucia bezpieczeństwa).

3. Ustabilizowanie (uspokojenie i ukierunkowanie emocji).

4. Gromadzenie informacji o bieżących potrzebach i troskach (identyfikacja potrzeb i niepokojów, zbieranie dodatkowych informacji).

5. Pomoc praktyczna (udzielenie natychmiastowej pomocy).

6. Powiązanie ze wsparciem społecznym (socjalnym) (pomoc w nawiązaniu kontaktów z osobami najbliższymi, które mogą udzielić pomocy).

${ }^{13}$ R.K. James, B.E. Gilliland, Crisis, s. 40-41.

${ }^{14}$ K. Kanel, A guide to crisis intervention, Stamford 2015, s. 19-20. 
7. Radzenie sobie z problemem (informacja o reakcjach stresowych i funkcjonowanie adaptacyjne).

8. Służby pomocnicze.

Autorka podkreśla, że w przypadkach rozwodów i separacji (w jednakowym stopniu dla osób trwających w związkach sakramentalnych lub nie), reakcją zdrowej osoby porzuconej mogą być stany dysfunkcyjne. Uważa również, że w stanach tych pomaga uświadomienie osobie porzuconej, że wiele osób przechodzi przez doświadczenie rozwodu ${ }^{15}$.

W warunkach polskich, gdzie 92\% osób stanowią katolicy w liczbie 32,7 mln osób ${ }^{16}$, liczba rozwodów - zaprzeczających przecież nauczaniu Kościoła katolickiego - wynosi od kilkunastu lat średnio ok. 65 tys. rocznie. Stanowi to ok. 30\% rozpadających się małżeństw w Polsce; pozostałe kończą się śmiercią jednego ze współmałżonków ${ }^{17}$. Oznacza to, że przytłaczająca większość rozwodów dotyczy osób, które ślubowały wierność, miłość i uczciwość małżeńską aż do śmierci.

Taki stan rzeczy uprawnia do odwołania się do wartości religijnych, nauczania Kościoła oraz Biblii, podczas pomagania porzuconym osobom w przezwyciężaniu kryzysu związanego ze zdradą i rozwodem. Ten cel jest realizowany przez istniejącą od 2003 r. Wspólnotę Trudnych Małżeństw „Sychar”, której spotkania noszą charakter „pierwszej pomocy”. Na spotkaniach każda osoba przeżywająca kryzys spotyka się z zainteresowaniem i zaangażowaniem innych osób, które też przeszły przez podobne doświadczenie. Wspólnota stara się budować poczucie bezpieczeństwa każdego członka na drodze wysłuchania i doradzania, co odpowiada pierwszym dwóm punktom z przytoczonej listy Kanel. Broszura informacyjna wspólnoty podaje: „W sytuacji kryzysu małżeńskiego szczególnie ważne jest wsparcie ze strony otoczenia, które bardzo często nie widzi innego wyjścia z zaistniałej sytuacji i doradza rozwód”18. W rzeczywistości jednak rozwód tylko pogłębia kryzys, pozostawiając porzuconą osobę w samotności i w nowych warunkach życia, wobec których jest on bezradny. Dlatego też

15 Tamże, s. 143-144.

16 W. Sadłoń, Annuarium Statisticum Ecclesiae in Polonia, Warszawa 2017, s. 4.

17 J. Stańczak, K. Stelmach, M. Urbanowicz, Małżeństwa oraz dzietność w Polsce, Warszawa 2016, s. 3-4.

18 Wspólnota trudnych małżeństw SYCHAR, Warszawa 2017, s. 4. 
członkowie Wspólnoty Trudnych Małżeństw SYCHAR stanowczo sprzeciwiają się mentalności rozwodowej i są zwolennikami ratowania malżeństwa. [...] Pragną w różny sposób pomagać wszystkim małżonkom, którzy chcą wytrwać $\mathrm{w}$ wierności, mimo że pojawiające się problemy wydają się często nie do udźwignięcia, np. zdrada, odejście współmałżonka i jego wejście w nowy związek ${ }^{19}$.

W ostatnich latach tę działalność poszerzono o dalszy etap pomocy nakierowanej na ustabilizowanie, uspokojenie i ukierunkowanie emocji, a także twórcze i konstruktywne wykorzystanie energii wyzwolonej przez kryzys. Odbywa się to w ramach Ruchu Wiernych Serc, wyrastającego $\mathrm{z}$ „Sycharu” a zrzeszającego osoby, które podejmują mocne postanowienie trwania $\mathrm{w}$ wierności pomimo niewierności współmałżonka. Decyzja ta w znacznej mierze wynika $\mathrm{z}$ motywacji religijnej, dlatego też wymagane jest, by osoba podpisująca deklarację wierności małżeńskiej i przynależności do RWS była w stanie łaski uświęcającej, przyjęła Komunię św., a także „sercem zawierzyła” i „ustami wyznała” wierność Jezusowi ${ }^{20}$. Takie podejście stanowi dobrą podstawę ku temu, by pomoc w wychodzeniu z kryzysu dla tych osób była zbudowana na podstawach biblijnych. Oczywiście, głównym zakładanym czynnikiem wspierającym jest nadprzyrodzona moc Boga objawiająca się w życiu poszczególnych osób w różny sposób, lecz czynniki psychologiczne odgrywają również ważną rolę. Spośród tych wymienianych w literaturze przedmiotu, chciałoby się zwrócić szczególną uwagę na następujące działania:

- odbudowa poczucia tożsamości i przywrócenie pozytywnej samooceny,

- przywrócenie poczucia sensu życia,

- reewaluacja zachodzących wydarzeń (odkrycie nie tylko ich sensu, ale też walorów pozytywnych),

- wyciszenie silnych emocji negatywnych na drodze przekierowania uwagi, a przede wszystkim przebaczenia,

- przywrócenie równowagi wewnętrznej na drodze ponownego odkrycia obszarów wewnątrzsterowności przy jednoczesnej akceptacji części obszarów pozostających poza kontrolą (zawierzenie ich Bogu daje poczucie, że one też są pod kontrolą),

19 Tamże.

20 Tamże, s. 71. 
- wypracowanie nowych mechanizmów radzenia sobie ze stresem, odbudowa ról społecznych i powrót do codziennych obowiązków.

Poniższy program spotkań formacyjnych ma na celu umożliwienie realizacji szans wynikających z sytuacji kryzysowej.

\section{SPOTKANIA FORMACYJNE RWS}

Specyfika Ruchu Wiernych Serc polega na tym, że kryzys małżeński jest przeżywany w samotności, w poczuciu odrzucenia przez współmałżonka sakramentalnego, który definitywnie nie chce powrócić do rozmów i mediacji. W tych warunkach mamy do czynienia $\mathrm{z}$ kryzysem osoby szukającej odniesienia do Boga osobowego, z którym relacje najczęściej zostały zaniedbane $\mathrm{w}$ jej życiu małżeńskim (czyli w rozpadającym się systemie rodzinnym). Bardzo często osoby należące do RWS uczestniczą w rekolekcjach i podejmują praktyki postne i modlitewne rzadko stosowane w sytuacjach niekryzysowych (np. Nowenna Pompejańska). Niektórzy skarżą się na nadmiar aktywności „duchowo ukierunkowanych”, co świadczy o ich niskiej efektywności. Dlatego też w programie formacyjnym uwzględniono takie czynniki, jak:

- stopniowanie (np. stopniowe pozbycie się ciężaru emocjonalnego na drodze przebaczenia, stopniowe zdobywanie wiedzy biblijnej i osiąganie kolejnych celów),

- systematyczność (codzienne czytanie Biblii i powracanie w myślach do rozpatrzonego tematu przez kilka tygodni aż do następnego spotkania),

- długotrwałość (cykl formacyjny pierwszego stopnia, nastawiony na ustabilizowanie i ugruntowanie, trwa trzy lata),

- powtarzanie (w ciągu trwania cyklu te same prawdy są kilkakrotnie ukazywane w różnych kontekstach biblijnych),

- długoterminowa zmiana perspektywy (nabranie dystansu do osobistej doznanej krzywdy, zmiana sposobu postrzegania własnej sytuacji, przekierowanie uwagi na działania Boga oraz na potrzeby innych osób, którym można pomóc w ich utrapieniu itp.).

Poniżej jest przedstawiony autorski plan „Rocznego studium Biblii w ramach formacji RWS” na wrzesień 2018 - sierpień 2019 r., w któ- 
rym każdy podrozdział obejmuje albo jeden temat, albo grupę tematów o zbliżonych celach i treściach. Przy każdym temacie są podane pytania, na które uczestnicy spotkań będą szukać odpowiedzi w Biblii i w doświadczeniu życiowym. Po pytaniach umieściłem krótką charakterystykę oddziaływań, mających pomóc uczestnikom w przezwyciężaniu kryzysu.

\subsection{ZDRADZONY I SPRZEDANY ZBAWICIEL RODZINY (RDZ 45,5)}

Centralną postacią tego studium jest Józef, ulubiony syn Jakuba-Izraela, znienawidzony przez braci bez przyczyny, który wyratował swoich krzywdzicieli ze śmierci głodowej. Pytanie, wokół którego toczy się dyskusja w czasie spotkania, brzmi: Co sprawiło, że mógł to uczynić?

Historia Józefa sprzedanego do niewoli przez braci jest mocno osadzona w wydarzeniach historycznych i ma wszelkie cechy relacji naocznych świadków (a nie mitu lub legendy ułożonej w czasach późniejszych). Uczestnik spotkań formacyjnych może „odnaleźć się” w obrazie Józefa, ponieważ sam, też ufając Bogu, doznaje krzywdy. Celem spotkania jest nakierowanie myślenia uczestników na to, by zaczęli się identyfikować również z końcowym etapem historii Józefa, gdzie dominującym motywem jest jego zdolność do przebaczenia i pojednania. Zaufanie Józefa Bogu nie oznacza, że kontrolował on sytuację i wiedział, jak wszystko się skończy, ale oznacza, że Bóg pokierował wydarzeniami z korzyścią dla Józefa i całej jego rodziny dzięki wierności Józefa Bogu. Takie spojrzenie pozwala uczestnikom odbudować utraconą równowagę między wewnątrzsterownością (nadmiernym poleganiem na sobie) i zewnątrzsterownością (pasywne przyglądanie się wypadkom). Równowaga ta jest bardzo istotna ze względu na jej wpływ m.in. na takie czynniki jak: nasilenie potrzeb, poczucie lęku i mechanizmy obronne (np. zwątpienie, projekcja, reakcja upozorowana, wyparcie, intelektualizacja $)^{21}$.

${ }^{21}$ W. Chaim, Umiejscowienie poczucia kontroli a nasilenie potrzeb, lęku i mechanizmów obronnych, „Studia Philosophiae Christianae” 32 (1996) 2, s. 275-283. 


\section{2. „JEDYNY WIERNY W CAŁYM JEGO DOMU” (LB 12,7)}

Biblia opisuje, jak Mojżesz, gorliwy obrońca praw mniejszości żydowskiej w Egipcie, odnosi porażkę i musi uciekać za granicę. Dopiero potem, po spotkaniu $\mathrm{z}$ Bogiem, jest w stanie wpłynąć na losy swojego ludu wyprowadzając go z Egiptu. Dlaczego jednak na początku odniósł porażkę? Jakie były przyczyny jego późniejszego sukcesu? Na czym polegała jego „wierność”, na którą zwraca uwagę werset Lb 12,7? Dlaczego „w całym Jego domu”? Jak to się ma do nas?

Historia Mojżesza, jednej z największych postaci w Historii Zbawienia, nie jest defiladą w chwale, tylko historią wzlotów i porażek. W czasie spotkania uczestnicy poznają rozterki Mojżesza, jego nieudolne próby służenia swojemu ludowi, które zakończyły się wygnaniem z kraju, a także sposób, w jaki udało mu się zrealizować wolę Boga w życiu swojego narodu. Jest to właściwie powtórka $\mathrm{z}$ zagadnień poruszonych $\mathrm{w}$ pierwszym spotkaniu, ale z naciskiem na wierność Mojżesza, do której odnosi się później również Nowy Testament (Hbr 3,5). Ma to utwierdzić uczestników w słuszności podjętej decyzji trwania w wierności oraz dostrzeżenie celu i sensu takich działań niezależnie od rozwoju wydarzeń. Biorąc pod uwagę, że kryzys łączy się w dużej mierze z doświadczeniem zniweczenia ważnych celów życiowych oraz poczuciem niemożności usunięcia przeszkód w ich osiąganiu ${ }^{22}$, odbudowanie perspektywy sensowności wydarzeń pomaga $\mathrm{w}$ przezwyciężaniu kryzysu.

\subsection{WIERNOŚĆ A GRZECH (1 KOR 6,18)}

Dlaczego nazwana w tym wersecie rozpusta (gr. $\pi$ opveía) jest tak niebezpiecznym grzechem, że trzeba od niej uciekać (gr. $\varphi \varepsilon v ́ \gamma \omega)$ ? Jak wierność chroni przed tym grzechem? Jak to działa w małżeństwach rozbitych?

Jest to kontynuacja tematu wierności w kontekście trwania. Omawiając problem grzechu rozpusty, uczestnicy nabierają pewności, że brak aktywności seksualnej nie stanowi takiego wielkiego problemu, jak grzech

${ }^{22}$ E. Włodarczyk, Zdarzenie losowe i sytuacja kryzysowa, w: Człowiek wobec krytycznych sytuacji życiowych. Z teorii i praktyki pracy socjalnej, red. E. Włodarczyk, I. Cytlak, Poznań 2011, s. 356-376. 
niewierności czy seks pozamałżeński. Autorzy biblijni dobitnie wykazują, że związek pozamałżeński generuje wiele zła, a pocieszenie i przyjemność $\mathrm{z}$ niego płynące są złudzeniem. Trwanie w czystości natomiast pozwala $\mathrm{w}$ utrzymaniu relacji z Bogiem ${ }^{23}$, która pozwala liczyć na Jego skuteczne działanie w moim życiu. Zmienia się perspektywa patrzenia uczestników na swój problem, który zaczyna być postrzegany jako szansa, czynnik motywujący do działania. Uczestnik spotkania uczy się wzbudzać podstawowe zaufanie do własnej osoby i do innych ludzi. Rodzi się w nim nadzieja, która w znacznym stopniu sprzyja przezwyciężeniu kryzysu. Zgodnie z opinią badaczy, „siła wewnętrzna człowieka bierze się z wierności wobec swojego wewnętrznego świata. Kto ma zaufanie do siebie, łatwiej znosi sytuacje trudne"24.

\section{4. „INTERESY" Z PANEM BOGIEM (HBR 10,30) ORAZ PRZEBACZENIE (MT 6,14)}

Bardzo często w sytuacjach kryzysowych pojawia się żal do Pana $\mathrm{Boga}^{25}$, że postąpił $\mathrm{z}$ nami niesprawiedliwie i nawet nieuczciwie. Bardzo dobrze ilustruje to dowcip o Żydzie, którzy przyszedł do rabina i się skarżył na Pana Boga: „Miałem żonę i interes warty 10 tysięcy rubli, ale splajtowałem i zmarła mi żona. Gdyby Bóg prowadził ze mną uczciwe interesy, to najpierw zmarłaby mi żona - wtedy mógłbym się ożenić z kobietą, która miałaby posag 10 tys. rubli - i następnie mógłbym splajtować. W ten sposób i ja miałbym żonę i 10 tys. rubli, i Bóg miałby żonę i 10 tys. rubli”.

Uczestnicy spotkania szukają odpowiedzi na pytania pomagające zrozumieć, że my nie możemy przekupić Pana Boga dobrymi uczynkami i wymusić na nim, by wszystkie wydarzenia toczyły się po naszej myśli. W szczególności zwracamy uwagę na to, że sprawiedliwy sąd Boży musi się skierować również przeciwko nam ze względu na nasze grzechy, i tyl-

${ }^{23}$ G. Krawiec, M. Rucki, Wychowanie do czystości w Prawie Mojżeszowym, „Roczniki Pedagogiczne” 8 (2016) 3, s. 101-119.

${ }^{24}$ H. Skłodowski, Psychologiczne wyzwania kryzysu, w: Człowiek w kryzysie psychospołeczne aspekty kryzysu, red. Skłodowski, Łódź 2010, s. 9-22.

${ }^{25}$ M. Dziewiecki, Zranienia $w$ relacjach międzyludzkich, https://opoka.org.pl/ biblioteka/I/IP/ md_zranieniarel.html (dostęp: 17.05.2018). 
ko miłosierdzie Boże daje nam szansę na zbawienie ${ }^{26}$. Stawiamy pytania: czy moje pojęcie o sprawiedliwości jest takie samo, jak Boże pojęcie? Jak wypadnę przed Bogiem, jeśli będę oceniany przez Niego sprawiedliwie? Jak oceniam innych, przede wszystkim moich krzywdzicieli - czy według sprawiedliwości, czy według miłosierdzia? Ile jest warte miłosierdzie $\mathrm{w}$ przeliczeniu na pieniądze?

Ludzkie wyobrażenia o Panu Bogu i o tym, jak On powinien zadziałać w danej sytuacji, prowadzą do frustracji i pogłębienia kryzysu, oraz do poczucia bycia porzuconym przez Pana Boga. Temat ten pokazuje, że sprawiedliwość Boga nie oznacza natychmiastowej ingerencji i zniszczenia złoczyńców. Za pomocą przypowieści wykorzystujących kwoty pieniężne Pan Jezus wyjaśnia, że nasze „zadłużenie” wobec Boga jest niewspółmiernie większe, niż krzywdy, jakie my sobie nawzajem wyrządzamy (np. Mt 18,23-35). Takie spojrzenie, $\mathrm{z}$ jednej strony, pozwala na zrozumienie własnej winy, a $\mathrm{z}$ drugiej, prowadzi do przebaczenia ${ }^{27}$. Przebaczenie bowiem polega na tym, że stając przed Bogiem człowiek nie żąda wymierzenia sprawiedliwości i ukarania krzywdziciela. „Oto przebaczam każdemu, kto zawinił przeciwko mnie [...]. Niech nikt nie będzie ukarany z mojego powodu" - takie słowa zawiera tradycyjna wieczorna modlitwa żydowska ${ }^{28}$.

W nawiązaniu do poprzednich tematów, a szczególnie do przykładu Józefa, uczestnicy zaczynają widzieć sens przebaczenia i podejmują kroki w celu pozbycia się ciężaru emocjonalnego. Powtórzenie tego samego zagadnienia $\mathrm{z}$ różnych perspektyw w ciągu dwóch spotkań pozwala na bardziej obiektywną ocenę swojej sytuacji i wyzwolenie $\mathrm{z}$ negatywnych emocji blokujących racjonalne działania.

$\mathrm{Na}$ drugim spotkaniu dotyczącym nakazu przebaczenia (Mt 6,14), uczestnicy szukają odpowiedzi na następujące pytania:

- Dlaczego Bóg domaga się, bym przebaczał?

- Co będzie, jeśli nie przebaczę krzywdzicielowi?

${ }^{26}$ Zob. np.: M. Rucki, Mor Severius Moses, M. Abdalla, A. Benyamin, Miłosierdzie Boże w tradycji judaizmu i Kościołów Wschodu, w: Oblicza miłosierdzia w Biblii, red. J. Jaromin, Wrocław 2016, s. 371-404.

${ }^{27}$ H. Wejman, Miłosierdzie Boga a duch skruchy i przebaczenia w zyciu człowieka, „Colloquia Theologica Ottoniana” 2 (2016), s. 185-200.

${ }^{28}$ P. Polonski (red.), Sidur szaarej tfila (nusach aszkenaz), „Jeruzalem” 5767 (2008), s. 446. 
- Ile razy mam przebaczać?

- Czy nie zostanę wykorzystany i ponownie skrzywdzony?

Szczególnie to ostatnie pytanie jest ważne w sytuacji kryzysu małżeńskiego, kiedy krzywdy (w tym zdrady) powtarzają się. Uczestnik uczy się, jak odróżniać działanie z miłością od pobłażliwości, a w razie potrzeby asertywnie sprzeciwiać się złu.

\section{5. „W JEGO RANACH JEST NASZE UZDROWIENIE" (IZ 53,5)}

Ludziom w kryzysie często się doradza, by się pomodlili i oddali sprawę Bogu. Jednak z reguły człowiek nie odczuwa natychmiastowej ulgi po wypowiedzeniu „aktu zawierzenia” i nie widzi żadnych zmian w zaistniałej sytuacji kryzysowej. W temacie 6 rozpatruje się szczegółowo sytuację, która doprowadziła do cierpienia i śmierci Pana Jezusa Chrystusa, oraz na zbawcze konsekwencje tejże męki. Na spotkaniu rozpatrywane są kwestię:

- Jak rany Jezusa mogą leczyć moje rany?

- Co oznacza „współcierpienie”?

- Jak moja krew może być dolana do ofiary Jezusa (Flp 2,17)?

Jedną z konsekwencji męki i śmierci Chrystusa jest zbudowanie naszej tożsamości dzieci Bożych, mogących zawsze liczyć na miłość i akceptację Ojca. Utożsamienie się z cierpieniem Jezusa i jakby „przejście” wspólnie z Nim tej drogi pozwala spojrzeć na własny problem z perspektywy Golgoty, tak, jak widzi go Jezus wiszący na krzyżu. Oprócz możliwości przewartościowania wydarzeń i odczuć, pojawia się szansa na zrozumieniu głębszego sensu wydarzeń, które są bolesne i dramatyczne. Uczestnicy mogą odzyskać egzystencjalną równowagę, odbudować poczucie tożsamości i własnej wartości, dostrzec ponownie sens własnego życia i odzyskać zdolność do działania (pozytywna dezintegracja).

\subsection{JEZUS WYWRACAJĄCY STOŁY (J 2,15)}

Sytuacja opisana w Ewangelii, gdzie Jezus Chrystus wywraca stoły w Świątyni Jerozolimskiej, ma podwójną implikację. Z jednej strony pokazuje, że Jezus potrafi z minuty na minutę zmienić układ sił i obiektywnie 
zaistniałą sytuację zewnętrzną. Z drugiej jednak sugeruje, że w Świątyni, gdzie miał być sprawowany kult Boży, kwitł egoizm i małostkowość. Bóg, panując nad okolicznościami, może w jednej chwili zmienić moją sytuację zewnętrzną, ale czy ja bym chciał, żeby On oczyścił moją „wewnętrzną świątynię"?

W czasie spotkania rozważane są pytania: Jak wyglądała sytuacja w Świątyni, zanim przyszedł tam Jezus? Jak wyglądała chwilę po Jego przyjściu? Czy wszyscy byli zadowoleni z tego, co zrobił Jezus? Czy ja chcę, by Jezus „powywracał stoły” w moim życiu? Od czego ostatecznie zależy każda sytuacja mojego życia? Czy zmiany wprowadzane przez Jezusa są na dobre, czy na złe?

Przekierowanie uwagi uczestników z niekontrolowanych okoliczności na swój własny stan wewnętrzny ponownie, z innej perspektywy, pomaga odbudować i umocnić równowagę między wewnątrzsterownością (nadmiernym poleganiem na sobie) i zewnątrzsterownością (pasywne przyglądanie się wypadkom).

\subsection{TRWANIE W BIBLII: „WSZELKIE PISMO OD BOGA NATCHNIONE [JEST] I POŻYTECZNE DO..." (2 TYM 3,16-17).}

$\mathrm{Na}$ podstawie poprzednich spotkań można dokonać pewnego podsumowania, że historie biblijne mają konkretne przełożenie na nasze życie, a ich znajomość pozwala na zmianę perspektywy, odzyskanie równowagi i rozwiązanie problemów emocjonalnych. Dlatego zachęta do systematycznego studiowania Biblii wywoła w tym momencie rezonans związany $\mathrm{z}$ osobistym doświadczeniem. Uczestnicy zastanawiają się nad pytaniami: Po co regularnie czytać Biblię? Czy można ufać temu, co w niej jest napisane? Jak Biblia może kształtować moje życie?

Systematyczność i wytrwałość w studiowaniu Biblii daje nie tylko możliwość zmiany postrzegania sytuacji kryzysowej, ale również buduje poczucie równowagi $\mathrm{w}$ odniesieniu do czegoś trwałego i pewnego. Podobnie modlitwa przestaje być „klepaniem” formułek lub „wymuszaniem” załatwienia przez Boga moich spraw, a przekształca się w twórczy dialog międzyosobowy. Te zagadnienia są rozpatrywane na dwóch kolejnych spotkaniach pt. „Trwanie w modlitwie (1 Tes 5,16-18)” oraz „Trwanie w Eucharystii (J 6,56)", w czasie których zadajemy sobie pytania: 
- Dlaczego Bóg czasami/często nie wysłuchuje modlitw?

- Jak modlić się, by to odnosiło skutek?

- Co mogę wyprosić u Boga, a czego nie mogę?

- Po co Pan Jezus ustanowił Eucharystię?

- Czy coś się zmienia po przyjęciu Komunii?

\section{8. "NAJPIERW IDŹ I POJEDNAJ SIĘ Z BRATEM SWOIM" (MT 5,24).}

W trakcie studium nieuchronnie pojawiają się pytania: Czym się różni pojednanie od przebaczenia? Skoro przebaczyłem, czy muszę się pojednać?

Doznana od współmałżonka krzywda jest tak wielka, że sama myśl o możliwym pojednaniu (czyli o odnowieniu wzajemnej zależności) napawa wielu przerażeniem. Niemniej jednak, nauczanie Chrystusa i Kościoła zakłada zdolność człowieka do przebaczenia i pojednania. Najogólniej ujmując, „przebaczenie jest [...] aktem osobistej decyzji, wyborem serca, które sprzeciwia się samorzutnej reakcji, by złem odpowiadać na zło"29. Lekan podkreśla, że „przebaczenie stanowi podstawowy warunek pojednania - nie tylko w stosunku Boga do człowieka, ale także w stosunkach wzajemnych pomiędzy ludźmi”30.

Jednak samo pojednanie wymaga zaangażowania obu stron i wzajemnych przeprosin. Zrozumienie tego jest przyczynkiem uzdalniającym do działania w nowych warunkach, kiedy krzywdziciel uzna swoją winę i poprosi o przebaczenie. Niezależnie od tego, jaka jest sytuacja obecna, gotowość do pojednania stanowi w znacznej mierze probierz ustabilizowania się i poradzenia sobie z kryzysem emocjonalnym.

\section{9. „BĘDZIECIE MOIMI ŚWIADKAMI AŻ PO KRAŃCE ZIEMI" (DZ 1,8)}

Uczestnicy, którzy wytrwali w formacji przez cały rok, mogą zaczynać przekierowywać swoją uwagę z własnych problemów na problemy

29 P. Mazurkiewicz, Przebaczenie i pojednanie, „Chrześcijaństwo - Świat - Polityka” 1 (2006), s. 7-32.

${ }^{30}$ J. Lekan, Przebaczenie w optyce miłosierdzia, „Teologia w Polsce” 10 (2016) nr 2, s. $59-77$. 
otaczających ludzi. Jak to ujął św. Paweł: Bóg pociesza nas w każdym utrapieniu, byśmy sami mogli pocieszać innych (2Kor 3,4). Zazwyczaj po roku trwania w studiowaniu Biblii, modlitwie i w stanie łaski uświęcającej ludzie zaczynają zauważać różnicę w jakości swojego życia. Niektórzy doznają wręcz cudownego, nadprzyrodzonego działania Boga, które objawia się w każdym przypadku indywidualnie. Mogą o tym skutecznie świadczyć, zachęcając innych do trwania w wierze. Dzięki temu mogą pomóc innym $\mathrm{w}$ zapobieganiu i rozwiązywaniu sytuacji kryzysowych, odkrywając na nowo swoją rolę w społeczeństwie i w rodzinie. W czasie spotkania poszukujemy odpowiedzi na pytania:

- Czy mam ewangelizować innych, skoro tak często upadam i tak niewiele wiem?

- Czy „świadectwo życia” nie wystarczy?

- Co mogę powiedzieć innym o Jezusie?

- Co, jeśli mnie nie posłuchają?

„To, co odróżnia świadectwo od „religijnej propagandy”, to właśnie zjednoczenie życia chrześcijanina z życiem samego Boga Ojca przez Chrystusa w Duchu Świętym" " Mając za sobą doświadczenie wychodzenia z kryzysu dzięki trwaniu w Chrystusie, uczestnicy spotkań mają szanse stać się skutecznymi świadkami Zmartwychwstałego, który działa w ich życiu.

\section{PODSUMOWANIE}

Doświadczenie poprzednich lat prowadzenia Ruchu Wiernych Serc pokazuje, że potrzebna jest właśnie taka formacja, dająca nie tylko chwilowe ukojenie, ale przywracająca zdolność do funkcjonowania w społeczeństwie. Opracowany na podstawie Biblii program jest w pełni zgodny z nauczaniem Kościoła Katolickiego na temat grzechu i świętości: „Każdy ochrzczony jest powołany do czystości. [...] Istnieją trzy formy cnoty czystości: jedna dotyczy stanu małżeńskiego, druga - wdowieństwa,

31 S. Płusa, Rola świadectwa w nowej ewangelizacji na przykładzie nowych ruchów eklezjalnych, „Verbum Vitae” 27 (2015), s. 275-296. 
trzecia - dziewictwa"32. Cnota czystości dotyczy również nienazwanej w Katechizmie formy czystości małżonka porzuconego, ale wciąż pozostającego w związku sakramentalnym. Pomaga mu nie tylko zachować czystość i stan łaski uświęcającej, ale też wyjść z kryzysu, odbudować poczucie własnej wartości i ufność w Bogu, odzyskać równowagę emocjonalną i psychiczną i powrócić do pełnienia ważnych ról społecznych, ukazuje cel i sens życia oraz pobudza do społecznie pożytecznych działań.

\section{LITERATURA}

Chaim W., Umiejscowienie poczucia kontroli a nasilenie potrzeb, lęku i mechanizmów obronnych, „Studia Philosophiae Christianae” 32 (1996) nr 2, s. 275-283.

Dziewiecki M., Zranienia w relacjach międzyludzkich, https://opoka.org.pl/biblioteka/I/ IP/ md_zranieniarel.html (dostęp: 17.05.2018).

James R.K., Gilliland B.E., Crisis Intervention Strategies, Belmont 2013.

Kanel K., A guide to crisis intervention, Stamford 2015.

Katechizm Kościoła Katolickiego, Poznań 2002.

Kłos-Skrzypczak A., Korzyści plynące z rodziny zakorzenionej w małżenstwie sakramentalnym - perspektywa Amerykańskich Biskupów Katolickich, „Family Forum” 7 (2017), s. 15-34.

Krawiec G., Rucki M., Wychowanie do czystości w Prawie Mojżeszowym, „Roczniki Pedagogiczne" 8 (2016) 3, s. 101-119.

Krok D., Satysfakcja ze zwiazku małżeńskiego a poziom hedonistycznego i eudajmonistycznego dobrostanu psychicznego małżonków, „Family Forum” 5 (2015), s. 141-160.

Kułaczkowski J., Rozwód a duszpasterstwo rodzin, w: Rodzina w nurcie wspótczesnych przemian, red. D. Krok, P. Landwójtowicz, Opole 2010, s. 45-65.

Kwak A., Rodzina i jej przemiany, Warszawa 1994.

Lekan J., Przebaczenie w optyce mitosierdzia, „Teologia w Polsce” 10 (2016) 2, s. 59-77.

Mazurkiewicz P., Przebaczenie i pojednanie, „Chrześcijaństwo - Świat - Polityka” 1 (2006), s. $7-32$.

McCubbin H.I., Figley C.R., Bridging Normative and Catastrophic Family Stress, in: Stress and the family: Coping with normative transitions (Vol. 1), H.I. McCubbin, C.R. Figley (Eds.), New York 2014, p. 218-228.

Płusa S., Rola świadectwa w nowej ewangelizacji na przykładzie nowych ruchów eklezjalnych, „Verbum Vitae” 27 (2015), s. 275-296.

Polonski P. (red.), Sidur szaarej tfila (nusach aszkenaz), „Jeruzalem” 5767 (2008).

${ }^{32}$ Katechizm Kościoła Katolickiego, 2348-2349. 
Rodrigues A.E., Hall J.H., Fincham F.D., What Predicts Divorse and Relationship Dissolution?, in: Handbook of Divorce and Relationship Dissolution, M.A. Fine, J.H. Harvey (Eds.), New York-London 2006, p. 85-112.

Rucki M., Mor Severius Moses, Abdalla M., Benyamin A., Miłosierdzie Boże w tradycji judaizmu i Kościołów Wschodu, w: Oblicza miłosierdzia w Biblii, red. J. Jaromin, Wrocław 2016, s. 371-404.

Sadłoń W., Annuarium Statisticum Ecclesiae in Polonia, Warszawa 2017.

Serafin A., Czyż M., Zdrada, https://psychologiapar.pl/2014/zdrada/ (13.05.2018).

Sikorski W., Zmienność interakcji w rodzinie uwarunkowana naturalnymi procesami jej rozwoju, w: Rodzina w nurcie wspótczesnych przemian, red. D. Krok, P. Landwójtowicz, Opole 2010, s. 89-102.

Skłodowski H., Psychologiczne wyzwania kryzysu, w: Człowiek w kryzysie - psychospołeczne aspekty kryzysu, red. Skłodowski, Łódź 2010, s. 9-22.

Stańczak J., Stelmach K., Urbanowicz M., Małżeństwa oraz dzietność w Polsce, Warszawa 2016.

Wejman H., Miłosierdzie Boga a duch skruchy i przebaczenia w życiu człowieka, „Colloquia Theologica Ottoniana” 2 (2016), s. 185-200.

Włodarczyk E., Zdarzenie losowe i sytuacja kryzysowa, w: Człowiek wobec krytycznych sytuacji życiowych. Z teorii i praktyki pracy socjalnej, red. E. Włodarczyk, I. Cytlak, Poznań 2011, s. 356-376.

Wspólnota trudnych małżeństw SYCHAR, Warszawa 2017. 